Lucyna Marzec

Instytut Filologii Polskiej, Uniwersytet im. Adama Mickiewicza w Poznaniu

\title{
Archiwum w biografii. Biograf/ka w archiwum
}

\section{Zwrot archiwistyczny}

W nekrologu Ryszarda Matuszewskiego autorstwa Anny Nasiłowskiej, który napisała w imieniu Międzynarodowego Stowarzyszenia Krytyków Literackich, możemy przeczytać: „Pozostawił po sobie dorobek swojego życia, dzienniki i uporządkowane archiwum”. Wyliczając trzy obszary działalności Matuszewskiego: dokonania naukowe i krytycznoliterackie, praktykę intymistyczną oraz cień każdej twórczej działalności - archiwum naukowca, redaktora, wydawcy, przyjaciela i znajomego wielu osobistości świata literackiego w Polsce, Nasiłowska nie tylko oddaje hołd autorowi Zapisków świadka epoki, ale także przyjmuje, że praktyka archiwistyczna jest równorzędna pracy twórczej jako aktywność wymagająca poświęcenia oraz jako drogocenna spuścizna. Zgadzam się z tym założeniem, a nekrolog Matuszewskiego - gatunek podniosły i sprzyjający osadzaniu ludzkiej działalności w tradycji - traktuję jako jeden z wielu sygnałów, iż zwrot archiwistyczny w humanistyce polskiej już dawno przestał być postulatem.

1 Archiwum Ryszarda Matuszewskiego zdeponowane w Bibliotece Narodowej w Warszawie zawiera dwadzieścia dwa tomy dziennika i obszerną korespondencję. 
Estyma, z jaką traktuje się cudze archiwa, kieruje uwagę na osoby, które je opracowują, oraz na tych, dla których są one materią pracy: biografów, reportażystów historycznych, naukowców (to wyliczenie ma charakter metonimiczny, nie gradacyjny). Ich przezroczystość została zakwestionowana niejednokrotnie, oskarżenia o literackość wiążą się z trudnościami w procedurach awansu zawodowego, a epitet „przyczynkarski” w przypadku opisu prac badawczych wywołuje negatywne konotacje. Status opracowujących archiwa i pracujących w archiwach jest ambiwalentny, nadwątlany kolejno przez: przełom antypozytywistyczny, hermeneutykę i hermeneutyki podejrzeń, konstruktywizm i narratywizm. Obok tysięcy biografii, które powstały tylko w xx i xxı wieku, ku radości, potrzebie, ciekawości czytelniczek i czytelników, piętrzy się stosik przełomowych dla humanistyki książek, które nie pozwalają ani na zawierzającą lekturę, ani na nieostrożne pisanie biografii.

Wysoki status teorii w humanistyce prowadzi do konstatacji, że nic prostszego, niż przyłapać biografa na gorącym uczynku kreacji w archiwum; nic trudniejszego, niż napisać zdanie twierdzące w biografii. Jednak podejrzliwość ma swoją przeciwwagę. To pragnienie (albo konieczność) opowiedzenia biografii. Amortyzuje ono sceptycyzm - lecz nie usuwa go - zarówno wobec cudzych, jak i wobec własnych praktyk badawczych w archiwum. Sprawia, że jest to w ogóle możliwe, mimo wszelkich wątpliwości i zastrzeżeń.

Do refleksji metakrytycznych związanych z archiwami i osobami wytwarzającymi w archiwach wiedzę chciałabym dodać kilka swoich przemyśleń. Wynikają one z praktyki kilkuletniej, toczącej się powoli, pracy nad twórczością i biografią Kazimiery Iłłakowiczówny, lecz wiążą się ze znacznie rozleglejszym zagadnieniem usytuowania ,ja” badawczego i pisarskiego w biografii. Postać biografa/biografki w archiwum i jej tekstowe alter ego często ujawniają się w biografiach, reportażach i pracach naukowych. Bywają też centrum opowieści literackich oraz wspomnieniowych, gatunków wytwarzanych i przetwarzanych w toku opowiadania biografii. Bywa, że fikcyjne figury biografa, archiwisty więcej mówią o realnych biografach i archiwistach niż ci sami o sobie; jednak nie warto przeceniać demistyfikacyjnej roli literatury w refleksji nad biografem/biografką w archiwum - te figury bywają użyte 
do celów innych niż odtajnianie wewnętrznych konfliktów, marginalizowanych $\mathrm{w}$ dyskursie naukowym czy narracjach dokumentarnych. To właśnie współczesne biografie rozpoczynają się albo kończą metarefleksjami o charakterze manifestu czy konfesji, rozważającymi umiejscowienie biografa/biografki i archiwum w procesie wytwarzania wiedzy. Nie tyle zbliżają się do literatury, ile prezentują świadomość teoretyczną i literackie obeznanie, szczególnie charakterystyczne dla współczesnych badaczek i badaczy literatury, podkreślających wielogatunkowy, narracyjny charakter swoich opowieści.

Tym, co łączy różne formy opowieści fikcjonalnych i niefikcjonalnych, jest silna obecność „ja” biografki/biografa. Paradoksalnie silna obecność „ja” czy „my” w akcie narracji nie równa się sile epistemologicznej. Wręcz przeciwnie, coraz częściej słabe (filozoficznie) ,ja” biografki/biografa, nadwątlone świadomością teoretyczną, ujawnia się jako ,ja” świadome swych uwikłań kulturowych i społecznych; niepewne siebie jako wytwórcy wiedzy; nade wszystko relacyjne, towarzyszące swojej bohaterce czy swojemu bohaterowi w procesie biografii i pisania biografii.

Ciekawią mnie wszelkie formy dotrzymywania towarzystwa jako zadania poznawczego i doświadczenia egzystencjalnego: stawanie u boku, służenie ramieniem czy wynoszenie pod niebiosa i ich różne wariacje. Droga do biografii prowadzi przez archiwum, przestrzeń spotkania (przez zapiski, przedmioty i rożne artefakty) oraz wspóltowarzyszenia żywych i martwych (podmiotów piszących i podmiotów opisywanych). Archiwum uruchamia obszary bliskie, lecz nie tożsame naukowemu poznaniu: pokłady pamięci i wyobraźnię. Podmiot w archiwum i podmiot w biografii przemieszcza się, rotuje: $\mathrm{z}$ tła cudzej biografii na plan pierwszy swojej opowieści (i z powrotem), z opowieści o wspólnej biografii do metakomentarza, z opisu archiwum w dynamiczną narrację ,jak to było naprawdę".

\section{Emancypacja paratekstu}

Archiwum, podobnie jak narracyjna instancja biografa/biografki, wyemancypowało się z paratekstu i bibliografii do opowieści bio- 
graficznej stosunkowo niedawno. W tej chwili zajmuje często miejsce centralne jako oś narracji bądź pieczęć paktu referencyjnego. Proces wyłuskiwania materiałów do biografii bywa równorzędną opowieścią wobec generowanej na jej podstawie historii: wiąże biografistykę z reportażem i esejem. Uwypukla znaczenie interpretacji i subiektywizmu w pisarstwie historycznym, choć czasem przecenia rolę biografa/biografki, czyniąc z pracy badawczej podporządkowanej, a więc służebnej wobec cudzej biografii - przestrzeń na opowieść o sobie. Efekty takich opowieści są niezwykłe zwłaszcza wtedy, gdy osoba biografa/biografki i jej metody pracy są równie ciekawe co podmiot (i przedmiot) biografii.

Wmontowanie metanarracji o pracy nad biografią jest nowością w reportażu czy pracy filologicznej, ale nie w biografistyce w ogóle, zwłaszcza takiej, która silnie wyrasta $\mathrm{z}$ form intymistycznych, jak wspomnienie czy edycja listów. Nie jest też nowością dla literatury. Jean Paul Sartre [1974], czyniąc Antoine'a Roquentina biografem de Rollebona, egzystencjalny dramat swego bohatera umiejscawia w bibliotece-archiwum, nad listami z przeszłości i białą kartą, którą trzeba wypełnić opowieścią. Jego problemy są typowe: szczątkowość materiału, trudne do scalenia domysły, znużenie czasochłonną pracą.

\section{Wyobraźnia filologiczna i przypadkowe odkrycie}

Alice Yaeger Kaplan [1990], omawiając rolę archiwum w pracy nad twórczością pisarza, przyznała, że w odkryciu źródeł antysemickich broszur, które Louise-Ferdinand Celine przerobił na potrzeby swoich pamfletów, pomogła jej zarówno wiedza, jak i wyobraźnia. Spacer po okolicach mieszkania Celine’a zaprowadził ją do dwóch najbliższych domowi pisarza antysemickich wydawnictw; szczegółowa kwerenda ujawniła, że prace Celine’a składają się z cytatów i plagiatorskich pożyczek. Kaplan wiedziała o tym wcześniej, gdyż przez trzy lata czytała rozproszone po bibliotekach antysemickie broszury, ponawiające te same postulaty, klisze i metafory, ale dopiero wyobrażenie tego, jakimi drogami mógł spacerować w swej dzielnicy Celine, przywiodło ją do odkrycia, które na nowo zaprasza do dyskusji o tych wywołujących obiekcje etyczne tekstach autora. 
Wyobraźnia filologiczna służy do konkretnych celów. Nasiłowska [2010: 298] w zakończeniu Lilki Kossak. Biografii poetki pisała:

Moja Lilka to swobodny esej biograficzny, zbudowany z elementów historycznych. Nie ma w nim fikcji, ale w pewnych momentach - wraz z czytelnikiem - możemy sobie też coś wyobrazić...

Wiąże autorkę-narratorkę $\mathrm{z}$ jej czytelnikami we wspólnym wysiłku dopowiedzenia tego, o czym milczą „źródła”. Monika Rudaś-Grodzka [2018: 21] wskazuje na fundamentalny związek wyobraźni i regul pisania biograficznego:

Wyobraźnia $[\ldots]$ co prawda czerpie inspirację z wiedzy historycznej, lecz w jeszcze większym stopniu z głębinowych pokładów pamięci i często wspomaga się elementami narracyjnymi, gdyż nie sposób przedstawić życia bez pewnej dozy fikcji,

którą generują podstawowe zasady pisarstwa: opis, opowiadanie, charakterystyka bohatera. Mimo że biograf wie, iż „Człowiek nie jest książką. Nie wiadomo, gdzie się zaczyna ani gdzie i kiedy zapisują się jego ostatnie stronice" - jak zaczyna biografię Haliny Mikołajskiej Joanna Krakowska [2011: 7-8] - to „narrator musi szukać drogi wyjścia z plątaniny faktów, mitów i wyobrażeń własnych oraz cudzych ku rekonstrukcji indywidualnej świadomości wpisanej w zbiorowość, w swoje miejsce i w swój czas".

Nie ma biografii bez narracji, tak jak nie ma biografii bez choćby szczątkowego archiwum. Podczas gdy biografki/biografowie tłumaczą się - czasami w poczuciu winy - z nierozrywalnego związku między biografią a literaturą, dla innych jest to jedyny aspekt, który broni biografistykę przed zarzutem indyferencji wobec etycznych i społecznych zadań pisarstwa:

Dzieła historyczne i biograficzne dostarczają nam empirycznych informacji, niezbędnych do podejmowania dobrych decyzji. $W$ istocie mogą one również uruchamiać pewne formy aktywności wyobrażeniowej, o ile napisane są w anga- 
żującym stylu. W takim stopniu zatem, w jakim skłaniają czytelnika do identyfikacji i sympatii, przypominają dzieła literackie. Dzieje się tak zwłaszcza wtedy, kiedy ukazują one wpływ okoliczności na emocje i świat wewnętrzny

- pisze Martha C. Nussbaum [2015: 269], powołując się na znane odróżnienia literatury i historii Arystotelesa w swej książce o relacji między wyobraźnią literacką a życiem publicznym. Narracji biograficznej wiele daje konwencja przygodowa czy detektywistyczne: wciąga, angażuje, uruchamia „prawo serii”. Znaleziska, skarby i fałszywe tropy są ich koniecznym elementem.

Czy można dokonać w uporządkowanym archiwum przypadkowego odkrycia? I tak się zdarza (Wilk Marka Hłaski odnaleziony kilka lat temu w Ossolineum), chociaż najczęściej topos przypadkowości oddaje sytuację zaskoczenia. Za pobudzającą wyobraźnię konfesją: „w zakurzonej, zapomnianej przez wszystkich teczce, przypadkiem odkryłam..." - stoi metodyczna skrupulatność, nie chaos poszukiwań. Ponawiane, aż do znużenia, te same czynności: zamówienie kolejnych zespołów, wpisanie się na karcie, założenie rękawiczek, rozsupłanie teczek bądź montowanie rolki z mikrofilmem do czytnika, korekta ostrości, przewijanie, zdjęcie roli, ułożenie papierów i zamknięcie teczki, oddanie teczki albo rolki dyżurnej bibliotekarce... Trudno poszukiwać tu sensacji, praca w archiwum nie ma nic wspólnego z przygodami Indiany Jonesa. Jednocześnie topos przypadkowości to nieusuwalny składnik pracy w archiwum, który odwzajemnia przygodność i niekompletność archiwalnych zbiorów. Archiwa nieczęsto dają jasne odpowiedzi na pytania, które im zadajemy. Mogą jednak pokierować w stronę, która zaprowadzi w rejony nieoczekiwane. Dlatego liczą się czasem najmniejsze znaleziska.

\section{Narracje i wyliczenia}

Opowieść o znaleziskach z wnętrza archiwum nieraz zastępuje opowieść biograficzną, np. wtedy, gdy brakuje do narracji materiału, gdy praca wyobraźni przyhamowuje. Dynamizm opowieści zanika na rzecz statycznego wyliczenia, jak w przypadku biografii 
Kazimiery Iłłakowiczówny autorstwa Joanny Kuciel-Frydryszak [2017]. Zestawienie początków kolejnych akapitów rozdziału o najmniej znanym okresie życia poetki czasu między rewolucją 1905 roku a odzyskaniem niepodległości jest typową próbką:

Ten czas przyniesie przełom: Iłłakowiczówna się nawraca.

Prowadziła w tej sytuacji bezpośredni dialog z Bogiem [...]

$\mathrm{Z}$ okresu tej potwornej choroby zapamiętała scenę $[\ldots]$

Potem dochodziła do siebie w Finlandii [...]

Jednym z cenniejszych dokumentów zachowanych w archiwum Iłłakowiczówny jest zaświadczenie z grudnia 1914 roku $[\ldots]$

Kolejny dokument to podpisane przez hrabinę Franciszkę $[\ldots]$

Po powrocie $\mathrm{z}$ frontu pracuje jako korektorka $\mathrm{w}$ drukarni w Piotrogrodzie [...]. [Kuciel-Frydryszak 2017: 105-107]

Powieściowe fragmenty dające wgląd w świat przeżyć wewnętrznych Iłłakowiczówny przeplatają się z przeglądem jej archiwum, które opiera się opowieści biograficznej, wprowadzając swój własny, nierówny rytm: rytm straty. Archiwum w opowieści biograficznej, zamiast zaświadczać i uwierzytelniać, odkrywa swoją własną niekoherencję, fragmentaryczność i przypadkowość. To też znane jest literaturze, która opowiada o umarlych ludziach i straconym świecie poprzez przedmioty: pozostałości, resztki, ruiny. W xx wieku takim magicznym przedmiotem był album fotograficzny.

Archiwum - zanim będzie pełnić konkretne funkcje w tekście - istnieje tak samo realnie, zajmując przestrzeń i zmieniając się w czasie, jak osoba pisząca biografię - i tej biografii bohater(ka). Nie jest więc ani tworem neutralnym, ani zbiorem gotowych dowodów w sprawie. Ale jakże często pragnie nimi być. 


\section{Pisma archontyczne}

Owo pragnienie przebija się przez wiele opowieści biograficznych, zwłaszcza tych, które scalają auto- i biografię. Ich szczególnym przypadkiem jest pośmiertne wspomnienie, przypominające poprzez archiwa połączenie fundamentalne dla wszelkich pism archontycznych: „pamiętam i mam w archiwum”. Znów przykład z moich badań nad twórczością Iłłakowiczówny: opowieść Ryszarda Matuszewskiego [1987] o poetce spiętrza i krzyżuje metaforyczne archiwa pamięci i materialne archiwa.

Matuszewski opowiada o kilku spotkaniach z Iłłakowiczówną, których większość miała charakter korespondencyjny i zawodowy, ale zintensyfikowała się ze względu na niespodziewane powinowactwa pomiędzy rodziną Matuszewskiego - rodzicami i ich rodzeństwem. Iłłakowiczówna znała ich jeszcze z czasów rewolucji w Piotrogrodzie, o czym Matuszewski dowiedział się z Trazymeńskiego zająca. Księgi dygresji [Iłłakowiczówna 1968]. Tym, co zjednuje mu życzliwość poetki, jest fotografia Iłłakowiczówny jako studentki. Redaktor otrzymał ją w prezencie od ciotki, a Iłłakowiczówna przy najbliższej sposobności pożycza ją, by „odfotografować” i włączyć do swojego archiwum.

Dzięki darowi - zarchiwizowanemu wspomnieniu siebie sprzed lat - młodszy kolega-redaktor przeistacza się ( $z$ listu na list, a równolegle w jego narracji na temat znajomości) w kogoś bliskiego, komu można powierzyć wspomnienia. Nie zgadzają się one z opowieścią zapamiętaną przez rodzinę Matuszewskiego: to jednak tylko szczegóły, rozbieżności jako punkty styczne dla wymiany kolejnych listów, niezbędne dla dynamiki korespondencji i potrzeby rozpamiętywania przeszłości, zawsze naznaczonej błędem, przeinaczeniem, spod znaku Mnemosyne i Lete.

Opis doświadczenia czytelniczego redaktora pokazuje, że Księga dygresji była księga konfesji dla tych, którzy czytali ją jako książkę o swoich rodowodach. Taki styl lektury jest typowy dla publikacji o charakterze wspomnieniowym, które powracają do zamkniętych epok - „przed wielką wojną”, „przed drugą wojną”, „W PRL-u” - gdy doświadczenie i pamięć (zarówno czytających, jak i piszących) przekraczają odcinki czasu mierzone wydarzeniami 
politycznymi, jednocześnie im towarzysząc. Spoglądanie wstecz wywołuje emocje, które nie potrzebują uwierzytelnienia, o ile są podzielane przez autora/autorkę i czytelnika/czytelniczkę. Jeśli Trazymeńskiego zająca... charakteryzował „uroczy, artystyczny i chronologiczny nieład” - jak pisał Matuszewski [1987: 195] - to dlatego, że był on „dla moich osobistych spotkań z panią Kazimierą mniej istotny".

W pismach archontycznych, tam, gdzie następuje „osobiste spotkanie”, nie liczy się ścisłość faktograficzna, ale sam kontakt, nawiązanie relacji, stworzenie przestrzeni dla rozmowy. Nawet wtedy, gdy wydaje się całkowicie nieprawdopodobna. Jak w przypadku opowieści Wandy Wasik [2010: 40] o tym, że spotkała schorowaną i niewidomą Iłłakowiczównę samotnie przechadzającą się po Poznaniu i otrzymała propozycję przyjaźni: „Potem widziałam ją tylko we śnie, w którym przyszła mnie pożegnać”. Piękny sen o wielkiej poetce poszukującej duchowej spadkobierczyni ziścił się w opowieści, której tytuł jest deklaracją uczuć, nie faktów: Spotkałam Itłakowiczównę.

A jednak uporządkowanie choćby najbadziej „uroczego nieładu” bywa konieczne i można go dokonać mimo życzliwości dla autorki wspomnień. Olof Lagercrantz [2011: 84 (1985)], poeta i biograf, opierając się na własnym doświadczeniu, przypomniał sprawę oczywistą:

Pisarz poszukuje w swej przeszłości materiału twórczego, przerabia go. [...] Rozporządzając suwerennie wspomnieniami, spogląda na dotychczasowe życie jak na swoją własność, a nie własność historii literatury.

Władysław Bodnicki [1982: 77-79, 87-90] w Muzach na Krupniczej, pragnąc zachować porządek biografii domów i ich mieszkańców na mitycznej krakowskiej ulicy, musiał nanieść konieczne poprawki na tom wspomnieniowy Iłłakowiczówny. W dyskretny sposób uprzytomniają one, do jakiego stopnia nie warto ufać pamięci poetki. Także Matuszewski, uruchamiając archiwa swojej rodziny, zestawia wspomnienia, nie rozstrzygając zarazem, kto pamiętał lepiej i czyje archiwa mniej korodowały. 
Biografów Iłłakowiczówny czekają niepewne rekonstrukcje, a przypadek poetki jest reprezentatywny, nie wyjątkowy:

Ze względów praktycznych autor biografii woli najczęściej kreślić życie pisarza od narodzin poprzez różne koleje losu aż do śmierci. W trakcie tej wędrówki ziemskiej spotyka on ciągle pisarza galopującego w przeciwnym kierunku. Dochodzi do kolizji. [Lagercrantz 2011: 83-84 (1985)]

Poetka myliła - umyślnie i nieumyślnie - daty, miejsca i ludzi. O legendarnej, choć tak typowej, zmianie daty urodzenia, pisały do tej pory przynajmniej trzy osoby, a każda tak, jakby czyniła to po raz pierwszy, ujawniając szczegółowo tok swego archiwistycznego śledztwa [Matuszewski 1987 (1983); Bystrzycki 2008; Kuciel-Frydryszak 2017].

Kiedy archiwum przyciąga biografów silniej niż bibliografia przedmiotowa, dowartościowuje podmiot badawczy, z czytelnika-kompilatora czyni odkrywcę. I choć jest to procedura konieczna w wielu przypadkach, jak w biografii osób, których archiwa cenzurowano (typowym procesem jest narastanie wiedzy w przypadku Brunona Jasieńskiego [zob. Jasieński 1972; Jaworski 2009: 246]), to nie zawsze prowadzi do odkrycia nowego lądu.

\section{Depozytariusze legendy}

Każda epoka widzi wyłącznie to, co widzi. Kiedy wychodzą na jaw wcześniej zatajone lub przysłonięte fakty, całokształt wizerunku ulega zmianie. Każdego biografa przenika myśl, iż wszystko, co pisze, rozpadłoby się, gdyby nieboszczyk wstał z grobu i zapuścił mu żurawia przez ramię

- pisał biograf Augusta Strindberga [Lagercrantz 2011: 78-79 (1985) ]. Obawa przed gniewem zmarłych, którzy życzyliby sobie, aby pewne fakty $\mathrm{z}$ ich życia ukryć i przemilczeć, bywa jednak silniejsza niż wybory biografa dyktowane kaprysami epoki. Dzieje się tak w przypadku opowieści o życiu Iłłakowiczówny, która aktywnie współtworzyła swą legendę biograficzną. Jej oddźwię- 
kami są dwie konkurencyjne biografie-wspomnienia autorstwa osób zaangażowanych w tworzenie poznańskiego środowiska literackiego: Józefa Ratajczaka (Lekcje u Itłakowiczówny. Szkice, wspomnienia, listy i wiersze, 1986) i Łucji Danielewskiej (Portrety godzin. O Kazimierze Iłłakowiczównie, 1987). Dla obojga tworzywem było archiwum prywatne oraz więź emocjonalna, którą nawiązali z poetką: Ratajczak - jako jej uczeń i protegowany poeta, Danielewska - jako lektorka i pomocnica. Ich opowieści sugerują, że w pewnym sensie działali (w mniejszym stopniu Ratajczak, w większym Danielewska) niczym ucieleśnione archiwa poetki, depozytariusze jej legendy biograficznej.

Iłłakowiczówna miała powiedzieć Danielewskiej [1987: 212] na kilka lat przed śmiercią zdania, które stanowią centrum Portretów godzin:

Pani też po latach będzie wspominała, że znała taką dziwaczną osobę i dziwaczne wokół niej sytuacje. Kiedy mnie już długo nie będzie, będą panią uważali za rzeczoznawcę na temat mojej literatury, a przecież nic innego jak listy są teraz moją literaturą. Teoretycznie to zaszczyt i przyjemność, że pani do mnie chadza czytać. Praktycznie, to się pani poświęca, ale ja do końca nie będę wiedziała, po co pani to robi.

Portrety godzin... jawią się jako konsekwencja zaprzysiężenia, przyjęcia powołania, służby Iłłakowiczównie. Służby bardzo trudnej, bo wymagającej dyskrecji, nieznoszącej sprzeciwu, upodrzędniającej „rzeczoznawcę”. W efekcie Portrety godzin... są książką z trudem ukrywającą ambiwalencję wobec swej bohaterki, która ujmowała legendą, ale odrzucała trudnym charakterem. Dlatego też jest to opowieść, w której kolejne godziny spotkań z poetką stają się pretekstem dla autobiografii zupełnie z Iłłakowiczówną niepowiązanej, ale sytuującej Danielewską w życiu literackim jej (oraz młodszych) generacji - jako poetkę i animatorkę kultury, aktywną, ale niedocenioną.

Słowo stało się ciałem tylko cześciowo: Danielewska do końca życia pełniła funkcję kustoszki „izby pamięci” Iłłakowiczówny, instytucji powołanej przez miejską Bibliotekę im. Edwarda 
Raczyńskiego (dziś Bibliotekę Raczyńskich), mieszczącej się w pokoju wynajmowanym przez Bibliotekę od prywatnego właściciela kamienicy. Nie przetrwała w pamięci kulturowej jako znacząca poetka.

Danielewska nie ujawnia swojego archiwum, opowieść o Ille toczy się tak, jakby jej narratorka miała doskonałą pamięć, zdolną pomieścić długie monologi poetki. Musiała jednak pracować na notatkach czy dziennikowych zapisach: celnie oddaje styl Iłłakowiczówny, a różnorodność opisywanych sytuacji, powiedzonek, wyznań, dowcipów poetki przekracza znacznie zawartość pozostawionych tomów wspomnieniowych, powtarza się natomiast w relacjach innych osób. Stylizatorskie umiejętności by tu nie wystarczyły.

Ratajczak - przeciwnie - do Lekcji... dołącza listy od poetki, tworzy antologię twórczości, każdy rozdział opatruje (włączonymi w tekst) przypisami. Ciąży w kierunku monografii typu „życie i twórczość”, odkrywa bliskość „przedmiotu badań” dopiero w tym historycznym momencie narracji, w którym rzeczywiście poznał „Iłłę z Gajowej”. Zaznacza od razu, że po spotkaniach z Iłłakowiczówną notował jej opowieści i dokonał kilku zapisów na taśmie magnetofonowej:

Mam to nagranie do dzisiaj. Zatrzymałem je na pamiątkę pomimo fatalnej jakości technicznej całego zapisu. Nie ośmieliłbym się zresztą dać tych szczątków rozmowy na antenę. Dla mnie jednak w głosie, którego teraz słucham, jest wszystko: ogromny mroczny pokój, postać poetki i jej serdeczna, czujna twarz o dużych, przejrzystych źrenicach, z którymi przerwany został nagle kontakt. [Ratajczak 1986: 115].

Prywatne archiwum pragnie intymnej kontemplacji i obecności zaangażowanego emocjonalnie podmiotu. Jest silną walutą zarówno legendy biograficznej, jak i praktyk badawczych - a jego moc wynika zarówno z oczywistej ciekawości poznawczej, jak i z niedostępności, fantazmatu „źródła”, „początku” oraz „przynależności”. „Pamiątki po zmarłym” stanowią materialny ślad nieobecnego i bezpowrotnie straconego, działają na zasadzie 
synekdochy oraz metonimii [Micir 2012]. Ich opracowanie towarzyszy kulturowej pracy żałoby.

Tanatyczna, żałobna wyobraźnia jest dla polskiego społeczeństwa charakterystyczna: „W kraju naszym, w jego tradycji, pamięć o ludziach, którzy byli kiedyś z nami, jest bardzo widoczna i czytelna” [Żynda 1988: 5] - zaczyna swoją pogadankę Kazimiera Itłakowiczówna we wspomnieniach starego ksiegarza Bolesław Żynda, wieloletni mieszkaniec Gajowej 4/8. Jako oczywiste dobro narodowe traktuje nakaz pamięci i szacunek dla zmarlych, Iłłakowiczównie zaś nadaje rysy wielkiej osobowości i wybitnej poetki.

Omawiam szczegółowo przypadek Iłłakowiczówny, ponieważ znam go najlepiej, a ponadto jest on charakterystyczny. Do podobnych wniosków prowadzi lektura biografii Wisławy Szymborskiej. Podczas gdy Joanna Szczęsna i Anna Bikont napisały biografię autoryzowaną, opublikowaną po raz pierwszy za życia noblistki [Bikont, Szczęsna: 1997 (2003, 2012)], Michał Rusinek [2016] z perspektywy sekretarza i archonta, dosłownie realizującego testament poetki - naniósł na ich wizję Szymborskiej drobne, lecz „autorskie” poprawki. Znamienne, że żałobną klamrą kompozycyjną Niczego zwyczajnego... są ostatnie dni Szymborskiej, opowiedziane szczegółowiej, dramatyczniej.

Rusinek odnosi się do swojej szefowej ze znacznie mniejszą ambiwalencją niż Danielewska wobec Iłłakowiczówny. Pozostawia też, w przeciwieństwie do Ratajczaka, narrację historycznoliteracką badaczom twórczości. Na taką opowieść dopiero przyjdzie pora. Wojciech Ligęza we wstępie do wyboru wierszy Szymborskiej w serii Biblioteki Narodowej pisze o „pisarce bez biografii” [Szymborska 2016: XI]. Głównej przyczyny tego braku badacz szuka w świadomych unikach poetki, motywowanych dystansem wobec niedyskretnych metod biograficznych. Istnieje jednak jeszcze inny ważny powód: luki w wiedzy, które są konsekwencją powoli opracowywanego archiwum (w Bibliotece Jagiellońskiej). Wiedza o Szymborskiej narasta i będzie narastać wraz z publikacją kolejnych tomów jej korespondencji i innych materiałów (niekoniecznie pochodzących $\mathrm{z}$ archiwum poetki), jednak książki Bikont i Szczęsnej oraz Rusinka mają status wyjątkowy, podparty sygnaturą autorską i pieczęcią bliskiej znajomości. 
W typowy dla archontów sposób sekretarz korzysta z pokładów własnej pamięci oraz różnego typu protez: fotografii, wywiadów, maili, zapewne notatek, a także dzienników ze wspólnych podróży, opisanych szczegółowo, dzień po dniu, w przypadku uroczystości noblowskich niemal z godziny na godzinę. Rusinek jako sekretarz współtworzył archiwum poetki . Zdanie: „Niestety, nie zachował się w archiwum [list - L.M.], więc cytuję z pamięci” [Rusinek 2016: 179] wskazuje na budujący i niszczący aspekt pracy archonta oraz jego symboliczną władzę: „pamiętam, że było w archiwum i zaświadczam swym imieniem, że było". Instytucjonalny wymiar władzy ustępuje jednak prawom Mnemozyne i zapomnienia oraz mocy więzi emocjonalnej Rusinka i Szymborskiej: „Nie umiem umiejscowić w czasie pewnego wydarzenia. Być może dlatego, że było bardzo silnym przeżyciem, które moja pamięć gdzieś zepchnęła” [Rusinek 2016: 191]; „Zaglądam do swoich esemesów z tamtych dni, telefony przechowują je bardzo długo; teraz, kiedy napiszę tę książkę, wreszcie będę mógł je wykasować [Rusinek 2016: 296] - tak Rusinek wspomina wiadomości pisane w ostatnie dni poetki. Nic zwyczajnego... przedstawia portret osoby oraz narrację o relacji. Z tego właśnie powodu książka o Szymborskiej jest też książką o Rusinku.

W każdą biografię bliskiej osoby musi wkraść się autobiografia, niekoniecznie jako znak egotyzmu czy ogrzewania się w cudzym świetle. Często „ja” biografa/biografki ujawnia zaangażowanie i jest wyrazem bliskości, choćby tymczasowej, dwojga biografii. O wspólnie przeżywanych momentach i doświadczeniach pisze się w liczbie mnogiej:

Pod koniec każdej dłuższej nasiadówki i bardziej intensywnego „szurania” papierami mówiliśmy zwykle, że zrobiliśmy kawał dobrej, nikomu niepotrzebnej roboty. Ta fraza pozwalała wrócić do rzeczywistości. [Rusinek 2016: 191]

Rusinek nawet przez chwilę nie sugeruje, że posiada wyjątkową wiedzę o Szymborskiej ani że ich relacja, życzliwa i intensywna, miała charakter poufały. Uprzywilejowana pozycja sekretarza i prezesa fundacji nie przekłada się w opowieści o noblistce na epi- 
stemologiczne usytuowanie narratora opowieści. Rusinek pisze jednoznacznie, że był obok, towarzyszył, ale nie zna sekretów ani kluczy do biografii poetki. Dlatego jego narracja powtarza konwencję biografii Szczęsnej i Bikont, ograniczając się do kilku ostatnich rozdziałów, o których pisać może z pozycji towarzysza poetki, podczas gdy reportażystki poprowadziły swą opowieść tradycyjnie, od kolebki do ostatnich chwil. Może zarazem uniknąć wszystkich tych tematów, o których niechętnie opowiadała Szymborska, niemal pozostawiając ją „poetką bez biografii” przednoblowskiej. Szacunek i dyskrecja to obok wścibstwa i kontroli równie silne filary gatunków intymistycznych i biograficznych. Kolejnym równie istotnym filarem jest dystans czasowy, oddzielający moment śmierci bohaterki od ostatnich wspomnień o niej tych, których żywo obchodziła. Wykorzystuje się go na różne sposoby.

\section{Rywalizacja i współpraca}

Pan de Rollebon był moim wspólnikiem: potrzebował mnie, aby być, a ja potrzebowałem go, aby nie czuć swego istnienia. Ja dostarczałem nie obrobionego materiału, który miałem do odstąpienia, z którym nie wiedziałem, co począć: istnienie, moje istnienie. Jego udziałem było przedstawianie. [Sartre 1974: 145]

Narrator Mdłości zarzuca pisanie biografii na rzecz istnienia. Silna opozycja pomiędzy doświadczaniem życia a pisaniem o cudzym życiu nabiera wymiaru tragicznego, ale zarazem czyni Roquentina przykładem biografa, który zamiast współpracować - konkuruje ze swoim bohaterem, nie mogąc wytrwać w swej służebnej roli. Jednym z kontekstów postawy Roquentina jest niewielka estyma dla biografistyki oraz intymistyki dla modernistów, a zwłaszcza awangardy. Tadeusza Peipera patobiografie były autobiografiami tranzytywnymi: mówiły nie o ich bohaterach, ale osuwającym się w chorobę autorze. Oddalały - pisze Jarosław Fazan [2010: 268] nie tylko od życia, ale i od awangardowej twórczości. Biografia jest gatunkiem czułym na zarzut tranzytywności także poza swą graniczną, patograficzną formą. 
Virginia Woolf [2015: 36] z pewnym trudnem próbowała dowartościować czytelniczą ciekawość:

Na przykład te biografie i autobiografie, żywoty wielkich ludzi, na ogół od dawna nieżyjących i zapomnianych, które stoją ramię $\mathrm{w}$ ramię z powieściami i poezją - czy mamy odmawiać czytania ich dlatego, że nie należą do „sztuki” [...] Może warto je czytać dla zaspokojenia ludzkiej ciekawości, jaka czasami ogarnia nas, gdy zatrzymujemy się wieczorem przed jakimś domem, gdzie zapalono już lampy, ale jeszcze nie zaciągnięto zasłon $[\ldots]$ ?

Woolf pisarka wybrała gry z formą biografii, „pokazują[ce] ludzi, którzy krzątają się wokół swych codziennych spraw, trudzą się, doświadczają porażek i sukcesów, jedzą, nienawidzą, kochają - aż w końcu umierają" [Woolf 2015: 36]. Jej Flush oraz Orlando to łże-biografie i modernistyczne arcydzieła. Ale Woolf-archontka pamięci napisała biografię Rogera Fry'ego, zmarłego w 1936 roku kolegi z grupy Bloomsbery.

Rola biografistyki rosła z dekady na dekadę "wieku dokumentu”, i choć Julian Barnes [1994 (1984)] w Papudze Flauberta odświeżył dylemat Roquentina - tym razem w szacie postmodernistycznej tragikofarsy - to postać biografa, który nie rzuca się maniakalnie w pisarstwo, nie tylko dlatego, że konwencje literackie układają się w prostsze wzory niż jego życie, zyskała na wartości. Lagercrantz [2011: 78-79 (1985)] pisal o jego społecznej roli:

Artyści pełnią dla nas funkcję zastępczą. To osoby publiczne, których najintymniejsze sekrety ciała i duszy wystawione są na pokaz. Pomaga to tym, którzy są zmuszeni do prowadzenia mniej jawnego trybu życia. Artyści czynią posługę bogom w świątyni kultury, a ich biografowie stają się mistrzami i sługami ceremonii.

Pisanie i czytanie „o sobie samym jako innym” bądź „o innym jako samym sobie” nie tyle przestaje konsternować i zawstydzać, 
ile zostaje rozpoznane jako jedna $\mathrm{z}$ funkcji literatury [zob. Felski 2016] w życiu jednostki i wspólnot interpretacyjnych.

Także „osobiste spotkanie” z bohaterem/bohaterką biografii zyskało inny wymiar. Rozumiane także metaforycznie jako spotkanie z duchem czy widmem przeszłości bywa konfrontacją - nie symbiotycznym wspólistnieniem, konfrontacją trudną i obciążającą biografa pragnieniami, sekretami i lękami bohatera. Uleganie im prowadzić może do katastrofy, jak przestrzega Derrida [2016 (2015) ], omawiając przypadek Hamleta. Zachęca zarazem do tego, by nie zajmować ambiwalentnej pozycji wobec „nawiedzającego” widma/ducha: walczyć z nim, mimo że to ono nas nawiedza. Monika Rudaś-Grodzka [2018: 20] polemizuje z katastroficzną wizją francuskiego filozofa:

[...] jeśli jesteśmy projektorem i przez nas przechodzi światło, możemy założyć, że przez nas patrzy widmo: czując jego obecność, dokonujemy jego mgławicowej substancjalizacji. Widmo podąża za naszym spojrzeniem, widzi naszymi oczami siebie, nam zaś wydaje się, że podążamy za nim.

Takie ujęcie decentralizuje problem dychotomii życia i pisarstwa, swojego istnienia i pracy nad biografią innej osoby. Nie stawia ich w relacji rywalizacji o władzę i dominację, ale zarazem nie czyni ich przezroczystymi w idealizującym geście. Dlatego autocharakterystyka biografki (Rudaś-Grodzka woli: „badaczki listów”) ukonkretnienia osobę piszącą, osobę, przez którą patrzy widmo, także po to, by odróżnić te dwie postaci od siebie: „Jeśli uznamy, że edycją listów jest wynik spotkania dwóch osób, to musimy też uświadomić sobie wszystkie ograniczenia i możliwości z tym związane" [Rudaś-Grodzka 2018: 17]. Krakowska [2011: 8] ujawnia podobną wrażliwość: „Rekonstrukcja cudzej świadomości po to, by przedstawić ją albo wręcz narzucić czytelnikowi, oznacza konieczność zadbania także o świadomość własną, uwikłaną w inne już miejsce i w inny czas”. Natomiast w zakończeniu biografii Marii Pawlikowskiej-Jasnorzewskiej Nasiłowska [2010: 298] stwierdza: 
Nad książką pracowałam pięć lat. Sam okres pisania był znacznie krótszy, długo trwało jednak oswajanie się z tematem. Największą barierą wydawało mi się to, że jestem kobietą zupetnie inną niż moja bohaterka. Potem pojęłam, że tak musi być i utożsamienie się byłoby najgorszą rzeczą, jaka tej opowieści mogłaby się zdarzyć na starcie.

Kiedy szacunek dla zmarlych nie ma, jak w przypadku wielu pism archontycznych, wymiaru legendotwórczego, to „osobiste spotkanie” przestaje być nawiedzeniem i tranzytywną projekcją. Polega na tym, by towarzyszyć. Biograf/ka, pracując z wnętrza archiwum, zyskuje tekstową reprezentację oraz osadzenie w konkretnej rzeczywistości, ale traci swój status wybrańca czy mistrzyni ceremonii: „, [.. ] nasza niewiedza, rosnąca proporcjonalnie w stosunku do wiedzy, którą zyskujemy poprzez nowe odkrycia źródel, jest kondycją epistemologiczną" [Rudaś-Grodzka 2018: 15]. Nadwątlone epistemologicznie ,ja” biografki/biografa, badaczki/ badacza jest konsekwencją przemian w teorii i poszukiwań „nowej filologii”. Jeśli konsekwencją zwrotu archiwistycznego jest wzmocnienie statusu dokumentalistyki oraz tekstologii, ich silne powiązanie z teorią, a zwłaszcza praktyką literaturoznawczą, to ,ja” badacze tych praktyk jest podejrzliwe wobec swoich możliwości poznawczych, a zarazem oddaje się pragnieniu poznawania.

Nowa filologia jest odpowiedzią na wyzwania nowej humanistyki [zob. Prussak, Bem, Cybulski 2013-2018; Czapliński, Nycz, Antonik i in., red. 2017; „Teksty Drugie” 2017]. W przypadku „przerabiania" xx wieku polega ona $\mathrm{m}$.in. na zawieszeniu syntez historycznoliterackich na rzecz rozproszonych prac interpretacyjnych, filologicznych odwiedzin w warsztatach pisarskich oraz ujęć biograficznych i socjologicznych. Powstałe w ostatnich dekadach podręczniki i kompendia pozostają nadal punktami orientacyjnymi, które jednak czeka rekonfiguracja. „Próby scalenia” xx wieku nie obejdą się bez poprawek, dopowiedzeń, a zapewne także rewizji ustalonego porząalku opartego na związkach literatury i wydarzeń społeczno-politycznych. Z jednej strony przyczyni się do tego metoda czy raczej wiązka metod badania procesu historycznoliterackiego. $\mathrm{Z}$ drugiej strony nowe ujęcia przyniosą archiwa, miejsce 
wytwarzania wiedzy podmiotu, świadomie sytuującego się wobec teorii, historii literatury i biografistyki, a zarazem podmiotu otwarcie ucieleśnionego i relacyjnego.

\section{Bibliografia}

Barnes Julian (1994), Papuga Flauberta, przeł. Adam Szymanowski, Czytelnik, Warszawa.

Bikont Anna, Szczęsna Joanna (1997), Pamiątkowe rupiecie, przyjaciele i sny Wisławy Szymborskiej, Prószyński i S-ka, Warszawa.

Bodnicki Władysław (1982), Muzy na Krupniczej, Wydawnictwo Literackie, Kraków.

Bystrzycki Przemysław (2008), Pani Kazimiera, w: Kiedy przebije się źródto, napija się wszyscy. W 25 rocznicę odejścia Kazimiery Itłakowiczówny, red. Jan Kanty Pytel, Uniwersytet im. Adama Mickiewicza w Poznaniu, Wydział Teologiczny, Poznań, s. 209-22o. Czapliński Przemysław, Nycz Ryszard, Antonik Dominik, Bednarek Joanna, Dauksza Agnieszka, Misun Jakub, red. (2017), Nowa humanistyka: zajmowanie pozycji, negocjowanie autonomii, Instytut Badań Literackich PAN, Warszawa.

Danielewska Łucja (1987), Portrety godzin. O Kazimierze Iłtakowiczównie, Czytelnik, Warszawa.

Derrida Jacques (2016), Widma Marksa. Stan dtugu, praca żałoby i nowa Międzynarodówka, przeł. Tomasz Załuski, PwN, Warszawa.

Fazan Jarosław (2010), Od metafory do urojenia: próba patografii Tadeusza Peipera, Wydawnictwo Uniwersytetu Jagiellońskiego, Kraków.

Felski Rita (2016), Literatura w użyciu, red. nauk. przekł. Ewa

Kraskowska, Ewa Rajewska, przeł. Joanna Borkowska, Katarzyna

Dembowy, Karolina Ignaczak, Agnieszka Janowska, Maja

Krysztofiak, Anna Michałowicz, Alicja Mużnik, Agata Ostrówka, Martyna Postolak, Wojciech Suchanke, Borys Szumański, Weronika Szwebs, Joanna Ścieszka, Anna Wawrzyniak i Aleksandra Wieczorkiewicz, Wydawnictwo „Poznańskie Studia Polonistyczne”, Poznań.

Jasieński Bruno (1972), Utwory poetyckie. Manifesty. Szkice, wstęp i oprac. Edward Balcerzan, Ossolineum, Wrocław.

Jaworski Krzysztof (2009), Dandys: słowo o Brunonie Jasieńskim, Iskry, Warszawa.

Kaplan Yaeger Alice (1990), Working in the Archives, „Reading the Archive: On Texts and Institutions", nr 77, s. 103-116. 
Krakowska Joanna (2011), Mikołajska: teatr i PRL, W.A.B., Warszawa.

Kuciel-Frydryszak Joanna (2017), Itła. Opowieść o Kazimierze

Itłakowiczównie, Marginesy, Warszawa.

Lagercrantz Olof (2011), O sztuce czytania i pisania, przeł. Jacek Kubitsky,

Czuły Barbarzyńca Press, Warszawa.

Matuszewski Ryszard (1987), Moje spotkania z panią Kazimiera, w: tegoż,

Powroty i pożegnania, Czytelnik, Warszawa, s. 187-220 [przedruk

z: „Tygodnik Polski” 1983, nr 17-19].

Micir Melanie (2012), Living in two tenses: the intimate archives of Sylvie

Townsend Warner, "Journal of Modern Literature”, vol. 36, nr 1, s. 191131.

Nasiłowska Anna (2010), Maria Pawlikowska-Jasnorzewska czyli Lilka Kossak: biografia poetki, Algo, Toruń.

Nussbaum C. Martha (2015), Wyobraźnia literacka, przeł. Maciej

Jakubowiak, w: Socjologia literatury. Antologia, red. nauk. Grzegorz

Jankowicz, Michał Tabaczyński, Korporacja Ha!art, Kraków,

s. 264-277.

Prussak Maria, Bem Pawel, Cybulski Łukasz , Sęczek Marlena

(2013-2018), Filologia XXI [seria], Wydawnictwo IBL PAN, Warszawa.

Ratajczak Józef (1986), Lekcje u Iłłakowiczówny. Szkice, wspomnienia, listy

i wiersze, Krajowa Agencja Wydawnicza, Poznań.

Rudaś-Grodzka Monika (2018), Biografia więzienna, w: Bronisława

Waligórska, Listy z Cytadeli 1886, Wydawnictwo IBL PAN, Warszawa.

Rusinek Michał (2016), Nic zwyczajnego. O Wistawie Szymborskiej, Znak,

Kraków.

Sartre Jean-Paul (1974), Mdłości, przeł. Jacek Trznadel, pIw, Warszawa.

Szymborska Wisława (2016), Wybór poezji, wstęp i oprac. Wojciech

Ligęza, Ossolineum, Wrocław.

„Teksty Drugie” (2017), nr 1: Nowa Humanistyka.

Wasik A. Wanda (2010), Spotkałam Itłakowiczównę, Bonami, Poznań.

Woolf Virginia (2015), Jak czytać ksiażki?, w: tejże, Eseje wybrane,

przeł. Magda Heydel, wybór i oprac. Magda Heydel, Roma Sendyka,

Karakter, Kraków, s. 33-46.

Żynda Bolesław (1988), Kazimiera Itłakowiczówna we wspomnieniach starego księgarza, Księgarnia Św. Wojciecha, Poznań.

Lucyna Marzec

\section{Archive in biography. Biographer in the archive}

The article discusses the role of the archive in biographical narrations and the relationship between the biographer and the archive in research 
practice. It discusses author's metacomment in contemporary biographies, articles on archive research, memoirs and novels (by A.Y. Kaplan, Ryszard Matuszewski, J.P. Sartre, Monika Rudaś-Grodzka, Joanna Krakowska, Joanna Kuciel-Frydryszak, Olof Lagercrantz and others). A key role in understanding their texts is played by a philological imagination and memory as elements of creating a biography, daily work in the archive and placing the biographer and the archive both in the process of creating knowledge and in the narrative figures.

Keywords: biography; archive; memory; Wisława Szymborska; Kazimiera Iłłakowiczówna.

Lucyna Marzec - doktor nauk humanistycznych, redaktorka „Czasu Kultury”, członkini Rady Naukowej Interdyscyplinarnego Centrum Badań Płci Kulturowej UAM. Publikuje artykuły z zakresu biografistyki, krytyki feministycznej i życia literackiego xx wieku. Kontakt: lucyna.marzec@amu.edu.pl. 
